STUDIA PRAWNO-EKONOMICZNE, t. CIV, 2017

PL ISSN 0081-6841; e-ISSN 2450-8179 $\quad$ s. 63-81

DOI: 10.26485/SPE/2017/104/4

\title{
Maria KARCZ-KACZMAREK*
}

\section{STATUS PRAWNY MUZEÓW UCZELNIANYCH - PROBLEMY PRAWNE I WYZWANIA PRAKTYCZNE}

\begin{abstract}
(Streszczenie)
Muzea uczelniane organizowane i prowadzone przez szkoły wyższe stanowią formę organizacyjną działalności kulturalnej. Oprócz swych podstawowych celów, związanych z gromadzeniem i trwałą ochroną dóbr naturalnego i kulturalnego dziedzictwa ludzkości, realizują one także dodatkowe zadania dotyczące działalności naukowej, dydaktycznej i oświatowej. Tworzenie muzeów uczelnianych jest cenną formą udoskonalania i uatrakcyjniania procesu naukowego i dydaktycznego oraz widocznym aspektem działań podejmowanych przez szkoły wyższe na rzecz społeczności lokalnych i regionalnych. Przepisy powszechnie obowiązujące nie odnoszą się wprost do problematyki muzeów uczelnianych, $\mathrm{z}$ uwagi na to kwestie te pozostają w gestii ich organizatorów, czyli szkół wyższych. Takie rozwiązanie prawne stanowi wyraz poszanowania autonomii uczelni, a także umożliwia prowadzenie samodzielnej polityki rozwoju. Funkcjonowanie muzeów uczelnianych, co do zasady, na podstawie statutów szkół wyższych rodzi jednak liczne kontrowersje o charakterze merytorycznym.
\end{abstract}

Słowa kluczowe: problematyka prawna muzeów; status prawny muzeów uczelnianych; statut szkoły wyższej; autonomia szkoły wyższej

\section{Wstęp}

Działalność muzeów obejmująca m.in. naukowe opracowywanie zgromadzonych zbiorów, prowadzenie działalności edukacyjnej, a także stymulowanie aktywności artystycznej odgrywa obecnie ważną i niekwestionowaną rolę w życiu

* Dr, Uniwersytet Łódzki, Wydział Prawa i Administracji, Katedra Prawa Administracyjnego i Nauki Administracji; e-mail: mkaczmarek@wpia.uni.lodz.pl 
kulturalnym społeczeństwa. Tym samym muzea stają się nie tylko placówkami utworzonymi dla ochrony dóbr kultury, ale instytucjami, które wpływają na rozwój cywilizacyjny. Tak postrzegana problematyka muzeów nawiązuje do ich starożytnej genezy. Pierwotnie muzea były ośrodkami życia naukowego. Słowo muzeum pochodzi z łaciny (musaeum), do której określenie to przeniknęło z greki. W starożytnej Grecji terminem mouseion określano miejsce lub świątynię przeznaczoną muzom i bóstwom poszczególnych gałęzi sztuki. Największą sławę zyskało Muzeum Aleksandryjskie założone przez Ptolemeusza I Sotera około roku 280 p.n.e. w Aleksandrii. Muzeum (muzejon) to stanowiło w istocie rzeczy instytut naukowy wzorowany na Arystotelesowskim Perypatosie, w którym zróżnicowaną działalność twórczą podejmowali uczeni oraz artyści. Za pierwsze, nowożytne muzeum publiczne uznaje się, ufundowane w $1679 \mathrm{r}$. przez prywatnego fundatora Eliasa Ashmola, Ashmolean Museum w Oksfordzie ${ }^{1}$. Warto zauważyć, że jeszcze w XVIII-wiecznej Encyklopedii Francuskiej wskazano, iż głównym zadaniem muzeów jest postęp wszystkich dziedzin wiedzy². Stwierdzenie to podkreślało dostrzegalny, silny związek działalności muzealnej oraz działalności naukowej. Tak pojmowane muzea, to nie były skostniałe izby pamięci, ale aktywne ośrodki badań i dokumentacji naukowej. Na kontynencie europejskim istotny wpływ na uznanie działalności muzealnej za zadanie publiczne miała rewolucja francuska 1789 r., która zmieniła podejście do dzieł sztuki, uznając je za dobro wspólne. Dekret francuskiego Zgromadzenia Narodowego z 1791 r. stanowił, że zbiory „mają stać otworem dla całej ludzkości, dla całego świata" 3 . Na podstawie wskazanego dekretu utworzono Muzeum Luwru (Musée du Louvre), gdzie wystawiono znacjonalizowane zbiory królewskie oraz skonfiskowane dobra prywatne ${ }^{4}$. Z czasem zauważalna stała się zmiana oczekiwań organizatorów muzeów co do charakteru prowadzonej przez nie działalności. Muzea zaczęto traktować jako instytucje powołane głównie do gromadzenia i ochrony cennych dóbr kultury, a podejmowana w nich działalność naukowo-badawcza zeszła na plan dalszy.

Por. B. Mansfeld, Muzea na drodze do samoorganizacji, DiG, Warszawa 2000, s. 5; J. Pruszyński, Ochrona zabytków w Polsce. Geneza, organizacja, prawo, PWN, Warszawa 1989, s. 25. Por. https://pl.wikipedia.org/wiki/Muzeum; stan na 10.04.2017 r.

2 Paryż 1765, t. X, s. 893-894. Podaję za B. Mansfeld, op. cit., s. 5.

3 S. Komornicki, T. Dobrowolski (red.), Muzealnictwo: praca zbiorowa, Związek Muzeów w Polsce, Kraków 1947, s. 19.

4 Ibidem. 


\section{Pojęcie prawne muzeum oraz rodzaje muzeów}

W obecnym stanie prawnym, zgodnie z zawartą $\mathrm{w}$ art. 1 ustawy z dnia 21 listopada 1996 r. o muzeach ${ }^{5}$ definicją legalną, muzeum jest jednostką organizacyjną nienastawioną na osiagganie zysku, której celem jest gromadzenie i trwała ochrona dóbr naturalnego i kulturalnego dziedzictwa ludzkości o charakterze materialnym i niematerialnym, informowanie o wartościach i treściach gromadzonych zbiorów, upowszechnianie podstawowych wartości historii, nauki i kultury polskiej oraz światowej, kształtowanie wrażliwości poznawczej i estetycznej oraz umożliwianie korzystania ze zgromadzonych zbiorów. $Z$ uwagi na wskazane cele muzea mogą być tworzone dla jednej lub wielu dziedzin działalności człowieka (dziedzictwo kulturalne) oraz dla tworów natury ${ }^{6}$ (dziedzictwo naturalne). Polska definicja ustawowa zbieżna jest z określeniem zawartym w Kodeksie Etyki dla Muzeów $\mathrm{ICOM}^{7}$ (Code of Ethics for Museums), zgodnie z którym muzeum jest trwale istniejącą instytucją, nienastawioną na osiąganie zysku, służącą społeczeństwu i jego rozwojowi, otwartą dla publiczności, która pozyskuje, konserwuje, udostępnia i wystawia w celu badawczym, edukacyjnym lub dla rozrywki materialne i niematerialne świadectwa ludzi oraz ich środowiska. Podstawowym celem funkcjonowania muzeum - w myśl Kodeksu ICOM - jest ochrona dziedzictwa naturalnego (natural heritage), czyli przedmiotów lub zjawisk przyrody, ważnych dla nauki lub mających znaczenie duchowe dla społeczności, a także ochrona dziedzictwa kulturalnego (cultural heritage) rozumianego jako jakakolwiek rzecz lub pojęcie uznane za mające znaczenie estetyczne, historyczne, naukowe lub duchowe.

Z prawnego punktu widzenia muzea stanową klasyczną formę zakładów publicznych $^{8}$. Wskazana kategoria - pierwotnie obejmująca szpitale oraz szkoły

5 Tekst jedn. Dz.U. z 2012 r., poz. 987 ze zm. zwana dalej u.m. lub ustawą.

${ }^{6}$ Jednym z pierwszych w Polsce gabinetów historii naturalnej był zbiór rodziny Czartoryskich. Znajdujący się w Puławach gabinet posiadał cenne i rzadkie zbiory skamieniałości. Kolekcja ta została nieomal całkowicie zniszczona przez rosyjski korpus gen. Derfeldena w czasie thumienia Powstania Kościuszkowskiego. Obecnie gabinet ten można byłoby określić mianem muzeum prywatnego. Por. M. Kosowski, Chetm 8 VI 1794, Inforteditions, Zabrze 2014, s. 56.

7 Kodeks uchwalono dnia 4 listopada 1986 r., następnie został on istotnie zmieniony na posiedzeniu ICOM w Seulu 8 października 2004 r. International Council of Museums - Międzynarodowa Rada Muzeów (ICOM) powstała w 1946 r. Z formalnego punktu widzenia ICOM jest stowarzyszeniem prawa francuskiego afiliowanym przy UNESCO i Radzie Społeczno-Gospodarczej ONZ. Zob. Code of Ethics for Museums (tłumaczenie), S. Waltoś, http://icom.museum/fileadmin/ user_upload/pdf/Codes/poland.pdf; stan na 10.04.2017 r.

${ }^{8}$ Podobnie J. Pruszyński, op. cit., s. 264. 
średnie i wyższe - wykształciła się we Francji w końcu XVIII w. Pojęcie zakładu publicznego (établissement public) nie było jednak zdefiniowane w ustawodawstwie ani jednolicie określane w literaturze przedmiotu. Istotny wpływ na ostateczny kształt pojęcia zakładu publicznego we Francji miało orzecznictwo sądowe oraz doktryna prawa administracyjnego (m.in. R. Connois, R. Drago, G. Vedel). W doktrynie francuskiej zakład publiczny definiowany jest jako swoista jednostka organizacyjna, charakteryzująca się osobowością prawną, wykonywaniem służby publicznej (service public) oraz wyodrębnieniem organizacyjnym $\mathrm{z}$ administracji scentralizowanej (administracji państwowej) ${ }^{9}$. W pozostałych krajach europejskich kategoria ta upowszechniła się w XIX w. We współczesnej polskiej doktrynie prawa administracyjnego zakład publiczny (zakład administracyjny) określany jest $m$.in. jako jednostka organizacyjna powołana do świadczenia usług niematerialnych na podstawie nawiązanego $\mathrm{z}$ użytkownikiem stosunku administracyjnoprawnego ${ }^{10}$. Zakłady publiczne cechują się swoistą formą organizacyjną, wyodrębnieniem środków osobowych oraz rzeczowych, wykonywaniem zadań publicznych w sferze socjalno-kulturowej, a także szczególnymi uprawnieniami ich organizatorów. Uprawnienia te dotyczą, m.in. utworzenia instytucji, nadania jej statutu oraz powołania i odwołania jej dyrektora. Cechą charakterystyczną wskazanych zakładów jest także zachodzący pomiędzy organami zakładu a jego użytkownikami stosunek o charakterze administracyjnoprawnym. Stosunek ten cechuje się nadrzędnością organów zakładu przejawiającą się w jednostronnym określaniu sytuacji prawnej użytkowników zakładu (m.in. w drodze aktów wewnętrznych) oraz możliwością użycia przymusu administracyjnego. Ta szczególna relacja prawna zachodząca pomiędzy organami zakładu a jego użytkownikami określana jest $w$ doktrynie prawa mianem władztwa zakładowego ${ }^{11}$. Zakłady publiczne mogą posiadać osobowość prawną, działają wówczas w imieniu własnym i na własną odpowiedzialność. Zakłady publiczne mogą także funkcjonować jako jednostki organizacyjne nieposiadające odrębnej od swojego organizatora osobowości prawnej.

Muzea mogą być klasyfikowane na podstawie zróżnicowanych kryteriów. Obowiązująca ustawa o muzeach, odwołując się do kryterium organizatora, wyróżnia muzea państwowe, samorządowe oraz muzea prywatne. Zgodnie z ustawą muzea

9 Z. Czarnik, J. Posłuszny, Zakład publiczny, w: R. Hauser, Z. Niewiadomski, A. Wróbel (red.), System Prawa Administracyjnego, t. 6, Podmioty administrujące, C.H. Beck, Warszawa 2011, s. 440-442.

10 J. Jendrośka, Zakład administracyjny, w: J. Boć (red.), Prawo administracyjne, Kolonia Limited, Wrocław 2007, s. 165.

11 Z. Czarnik, J. Posłuszny, op. cit., s. 445-475. 
państwowe tworzone są przez organy administracji rządowej (w tym ministrów i kierowników urzędów centralnych), muzea samorządowe stanowią zaś jednostki utworzone albo przejęte przez jednostki samorządu terytorialnego (gminy, powiaty, województwa samorządowe). Z kolei do kategorii muzeów prywatnych zaliczyć należy muzea tworzone przez osoby fizyczne, osoby prawne lub jednostki organizacyjne nieposiadające osobowości prawnej. Ustawodawca nie odnosi się wprost do kategorii muzeów kościelnych, wydaje się więc, iż zaliczone one powinny być do grupy muzeów prywatnych. Należy jednak zauważyć, że zgodnie $\mathrm{z}$ ustawą o muzeach $\mathrm{w}$ sprawach nieuregulowanych zastosowanie mają przepisy ustawy z dnia 25 października 1991 r. o organizowaniu i prowadzeniu działalności kulturalnej ${ }^{12}$. Z kolei przepis art. 38 tej ustawy stwierdza, że działalność kulturalną organizowaną i prowadzoną przez kościelne osoby prawne regulują odrębne przepisy. Zatem do muzeów kościelnych będą mieć zastosowanie przepisy ustawy o muzeach oraz odpowiednie przepisy dotyczące zasad funkcjonowania kościołów i związków wyznaniowych w Polsce ${ }^{13}$. Biorąc pod uwagę wskazany ustawowy podział muzeów, wątpliwości może budzić status prawny muzeów uczelnianych, utworzonych i funkcjonujących w ramach uczelni publicznych. Uczelnie publiczne, zgodnie z Prawem o szkolnictwie wyższym ${ }^{14}$, tworzone są przez państwo, które reprezentowane jest przez właściwy organ władzy lub administracji publicznej. Uczelnie, w myśl art. 12 P.s.w., posiadają osobowość prawną, czyli jako odrębne osoby prawne działają we własnym imieniu i na własną odpowiedzialność. Utworzone przez państwo uczelnie publiczne określić można zatem - z uwagi na publicznoprawny charakter organizatora oraz publiczny charakter przepisów stanowiących podstawę ich działalności - mianem publicznych osób prawnych. Czy zatem tworzone przez publiczne osoby prawne jednostki organizacyjne, $w$ tym muzea, należy określać mianem prywatnych? Podobne wątpliwości prawne odnieść można do statusu prawnego muzeów tworzonych przez samorządy zawodowe zawodów zaufania publicznego, np. przez adwokaturę ${ }^{15}$. Wskazane zrzeszenia publiczne w świetle postanowień art. 17 ust. 1 Konstytucji RP ${ }^{16}$ mają bowiem

2 Tekst jedn. Dz.U. z 2012 r., poz. 406 ze zm.

13 Por. ustawa z dnia 17 maja 1989 r. o stosunku Państwa do Kościoła Katolickiego w Rzeczypospolitej Polskiej (tekst jedn. Dz.U. z 2013 r., poz. 1169 ze zm.).

14 Ustawa z dnia 27 lipca 2005 r. (tekst jedn. Dz.U. z 2016 r., poz. 1842 ze zm., zwana dalej P.s.w.).

15 Przykładem jest Muzeum Adwokatury Polskiej utworzone przez samorząd adwokacki w dniu 20 listopada 1975 r. Muzeum jest unikalną w skali europejskiej placówką posiadającą cenne zbiory starodruków. Muzeum utrzymuje Naczelna Rada Adwokacka, http://www.nra.pl/nra. php?id=786; stan na 01.03.2017 r.

16 Konstytucja RP z dnia 2 kwietnia 1997 r. (Dz.U. z 1997 r., nr 78, poz. 483 ze zm.). 
status korporacji publicznych, stanowiąc istotną formę decentralizacji władzy publicznej ${ }^{17}$. Wydaje się, iż bardziej właściwym ujęciem statusu prawnego muzeów tworzonych przez uczelnie publiczne oraz zrzeszenia publicznoprawne byłoby umieszczenie ich w kategorii jednostek publicznych. Korzystnym rozwiązaniem ustawowym wskazanej kwestii mogłoby być wprowadzenie do ustawy o muzeach podziału na muzea publiczne (tworzone przez organy państwowe, jednostki samorządu terytorialnego oraz osoby (zrzeszenia; korporacje), publicznoprawne oraz muzea niepubliczne (tworzone przez osoby fizyczne i osoby prawne o charakterze prywatnym).

Muzea kategoryzowane mogą być także na podstawie kryterium funkcjonalno-rzeczowego. W literaturze przedmiotu Z. Żygulski, odwołując się do wskazanego kryterium, wyróżnił muzea: artystyczne, historyczne, archeologiczne, przyrodnicze, techniczno-naukowe oraz gospodarcze ${ }^{18}$. Zdaniem P. Antoniak wprowadzenie typologii na podstawie kryterium funkcjonalno-rzeczowego wymaga rozważenia pod kątem celowości. Aktualne tendencje rozwojowe muzealnictwa zmierzają bowiem do traktowania muzeum jako instytucji majątkowej oraz kreatywnej, stanowiącej w danym miejscu (regionie, kraju) formę stymulowania tworzenia nowych form kultury i nauki. Muzea stać się mają instytucjami łączącymi edukację i rozrywkę oraz prowadzącymi zróżnicowaną działalność badawczo-naukową. $\mathrm{Z}$ uwagi na to, współczesne muzeum powinno być przede wszystkim muzeum transkulturowym, a tego rodzaju muzeum jest ze swej istoty muzeum tworzonym dla wielu dziedzin działalności człowieka oraz tworów natury ${ }^{19}$. Funkcjonalno-rzeczową klasyfikację muzeów na gruncie obowiązujących przepisów wprowadza rozporządzenie Rady Ministrów z dnia 24 grudnia 2007 r. w sprawie Polskiej Klasyfikacji Działalności (PKD) ${ }^{20}$. Rozporządzenie to działalność muzeów zalicza do Sekcji R Działalność zwiąana z kultura, rozrywka i rekreacja. Z kolei Podklasa 91.02.Z Działu 91 Działalność bibliotek, archiwów, muzeów oraz pozostała działalność związana z kultura obejmuje działalność muzeów wszystkich rodzajów, takich jak: a) muzea sztuki, biżuterii, mebli, strojów, ceramiki, srebra stołowego, b) muzea historii naturalnej, nauki i techniki, historyczne, włączając muzea wojskowe i izby pamięci, c) pozostałe muzea wyspecjalizowane, d) muzea na wolnym powietrzu. Wskazany funkcjonalno-

17 Zob. M. Karcz-Kaczmarek, Rola samorzadów zawodowych w dostępie do niektórych zawodów, w: Prawo administracyjne materialne, Wolters Kluwer, Warszawa 2016, s. 597-600.

18 Z. Żygulski Jr, Muzea na świecie. Wstęp do muzealnictwa, PWN, Warszawa 1982, s. 81-106.

19 P. Antoniak, Ustawa o muzeach. Komentarz, Wolters Kluwer, Warszawa 2012, s. 44.

20 Dz.U. z 2007 r., nr 251, poz. 1885 ze zm. 
-rzeczowy podział, mający znaczenie głównie dla celów statystyki, ewidencji i dokumentacji oraz rachunkowości, abstrahuje od statusu prawnego muzeów.

W świetle powyższych stwierdzeń i przedstawionych kategoryzacji stwierdzić należy, że muzea stanowią zróżnicowaną wewnętrznie kategorię zakładów publicznych, świadczących usługi niematerialne w zakresie kultury.

\section{Utworzenie i organizacja muzeum uczelnianego}

Omówienie statusu prawnego muzeów uczelnianych oraz wskazanie trybu ich powoływania wymaga odwołania się do przepisów ustawy o muzeach oraz przepisów Prawa o szkolnictwie wyższym. Zgodnie z art. 6 u.m. muzeum działa na podstawie statutu nadanego przez organizatora, w uzgodnieniu z ministrem właściwym do spraw kultury i ochrony dziedzictwa narodowego. Ustawa o muzeach odróżnia statut właściwy od statutu muzeum w organizacji. Statut muzeum w organizacji zawiera jedynie postanowienia regulujące proces organizowania danej jednostki i obowiązuje wyłącznie do czasu zakończenia tego procesu. Za dzień zakończenia organizowania muzeum ustawodawca przyjmuje dzień otwarcia wystawy stałej. Po tym dniu organizator nadaje muzeum właściwy, docelowy statut. Statut muzeum określa w szczególności: 1) nazwę, teren działania i siedzibę muzeum; 2) zakres działania; 3) rodzaj i zakres gromadzonych zbiorów; 4) organ zarządzający i nadzorujący oraz organy doradcze i sposób ich powoływania; 5) źródła finansowania działalności; 6) zasady dokonywania zmian w statucie; 7) zasady prowadzenia jako dodatkowej działalności gospodarczej, jeżeli muzeum zamierza taką działalność prowadzić. Na podstawie statutu nadawanego we wskazanym ustawowym trybie funkcjonują muzea posiadające osobowość prawną. Zgodnie bowiem z przepisem art. 6 ust. 6 u.m. jednostki nieposiadające osobowości prawnej, $\mathrm{w}$ tym muzeum funkcjonujące $\mathrm{w}$ ramach struktury innej jednostki organizacyjnej, działają na podstawie regulaminu nadanego przez organizatora. Ustawodawca nie odniósł się wyraźnie do wymogu uzgadniania regulaminu z właściwym ministrem, jednocześnie jednak zdanie drugie wskazanego ustępu 6 art. 6 u.m. stanowi, że przepisy ust. 1-4 art. 6 stosuje się odpowiednio do regulaminu. Stwierdzić zatem można, że pomimo braku wyraźnego ustawowego wymogu uzgadniania, regulaminy muzeów prywatnych także powinny być przyjmowane w uzgodnieniu z ministrem właściwym do spraw kultury i ochrony dziedzictwa narodowego. Do muzeów prywatnych odpowiednie zastosowanie będą mieć także przepisy dotyczące statutu [w tym przypadku regulaminu] muzeum $\mathrm{w}$ organizacji oraz postanowienia dotyczące niezbędnych 
elementów konstrukcyjnych tego aktu zakładowego. Warto zauważyć, iż polski ustawodawca aż do roku 2007 w ogóle nie przewidywał odrębnej procedury tworzenia muzeów prywatnych. Instytucja regulaminu muzeum prywatnego wprowadzona została nowelizacją ustawy o muzeach z dnia 29 czerwca $2007 \mathrm{r}^{21}$ W uzasadnieniu ${ }^{22}$ noweli zauważono, że na gruncie dotychczas obowiązujących przepisów pojawiały się wątpliwości dotyczące statusu muzeów nieposiadających osobowości prawnej (co dotyczyło m.in. muzeów prywatnych), w tym szczególnej kategorii muzeów działających w strukturach organizacyjnych innych podmiotów, np. muzeów uniwersyteckich, teatralnych itp. W praktyce kwestią sporną pozostawało m.in. zagadnienie, czy instytucja kultury nieposiadająca osobowości prawnej może uzyskać status muzeum w rozumieniu ustawy o muzeach, a także problem rodzaju aktu tworzącego muzeum prywatne. Dodany do ustawy o muzeach w 2007 r. przepis rozwiązał wskazane problemy, stanowiąc, że instytucje prywatne działają na podstawie regulaminów nadawanych przez ich organizatorów. Na mocy wskazanej nowelizacji statuty funkcjonujących w tamtym czasie muzeów nieposiadających osobowości prawnej przekształcone zostały na regulaminy. Zmiana formy prawnej aktu będącego podstawą działalności omawianych jednostek kultury dokonana została z mocy prawa i nie wymagała podejmowania żadnych dodatkowych działań przez zainteresowane instytucje.

Stosownie do treści art. 6 ust. 6 u.o.m. należałoby stwierdzić, że muzea uczelniane działają na podstawie regulaminów nadawanych przez organizatorów, czyli szkoły wyższe $w$ uzgodnieniu z ministrem właściwym do spraw kultury i ochrony dziedzictwa narodowego. Ustawodawca nie precyzuje jednak trybu wskazanych uzgodnień, a w przypadku instytucji uczelnianych wydaje się to mieć zasadnicze znaczenie. W literaturze przedmiotu wskazuje się, iż uzgodnienie to dokonywane jest na wniosek podmiotu znajdującego się poza strukturami aparatu administracji publicznej i z uwagi na to powinno ono przyjmować formę decyzji administracyjnej, a co najmniej kwalifikować się jako inny akt lub czynność z zakresu administracji publicznej podlegający zaskarżeniu do sądu administracyjnego ${ }^{23}$. Pogląd ten wydaje się uzasadniony także w świetle orzecznictwa sądowoadministracyjnego. Zdaniem Wojewódzkiego Sądu Administracyjnego w Warszawie ${ }^{24}$ kodeks postępowania

21 Dz.U. z 2007 r., nr 136, poz. 956.

22 Sejm RPV Kadencji Nr druku: 1598, http://orka.sejm.gov.pl/Druki5ka.nsf/0/E44B010685003C90C12572BA00646C81/\$file/1598.pdf; stan na 01.04.2017 r.

23 P. Antoniuk, op. cit., s. 71.

24 Por. wyrok WSA w Warszawie z dnia 19 czerwca 2006 r., III SA/Wa 393/06 oraz wyrok NSA z dnia 17 maja 2007 r., II GSK 319/06; http://orzeczenia.nsa.gov.pl; stan na 10.04.2017 r. 
administracyjnego ${ }^{25}$ nie zawiera legalnej definicji decyzji administracyjnej. W doktrynie i orzecznictwie sądowym przyjmuje się, że decyzja administracyjna jest władczym przejawem woli organu administracji publicznej, wydanym w postępowaniu toczącym się przed tym organem $w$ indywidualnej sprawie administracyjnej i stanowi jej rozstrzygnięcie. Zgodnie z przepisem artykuł $104 \S 2$ k.p.a. decyzja rozstrzyga sprawy, co do istoty w całości lub w części, albo w inny sposób kończy sprawę w danej instancji. Z uwagi na to, za decyzję administracyjną uznaje się takie oświadczenie woli organu administracyjnego, które wywiera skutki prawne w sferze stosunku administracyjnoprawnego. Na zakwalifikowanie danego aktu do kategorii decyzji administracyjnych nie wpływa jego nazwa, ale treść i skutki prawne, jakie dane rozstrzygnięcie administracji publicznej wywołuje. Biorąc zatem pod uwagę fakt, iż uzgodnienie statutu przez właściwego ministra wywołuje skutki w sferze uprawnień administracyjnoprawnych - przesądza bowiem o możliwości prowadzenia muzeum - akt ten należy zakwalifikować jako indywidualny akt administracyjny (decyzję administracyjną).

Powyższe ustalenia należy skonfrontować z przepisami ustawy Prawo o szkolnictwie wyższym, zgodnie $\mathrm{z}$ którymi uczelnia - na zasadach określonych w ustawie - jest autonomiczna we wszystkich obszarach swojego działania. Ponadto przepis art. 4 ust. 5 tej ustawy stanowi, że organy administracji rządowej i organy jednostek samorządu terytorialnego mogą podejmować decyzje dotyczące uczelni tylko w przypadkach przewidzianych w ustawach. Postanowienie to stanowi rozwinięcie przepisu art. 70 ust. 5 Konstytucji RP zapewniającego autonomię szkół wyższych na zasadach określonych w ustawie. Zdaniem doktryny prawa dotyczy to m.in. tzw. autonomii instytucjonalnej ${ }^{26}$, czyli autonomii uczelni wyrażającej się $\mathrm{w}$ jej stosunkach $\mathrm{z}$ władzami publicznymi ${ }^{27}$. Jeżeli zatem obowiązujące przepisy nie przewidują wydawania przez ministra właściwego do spraw kultury i ochrony dziedzictwa narodowego decyzji w sprawie uzgodnienia regulaminu muzeum uczelnianego, możliwość taka wydaje się być wyłączona. Oceniając kierunek zmian ustawowych, należałoby stwierdzić, iż prawo w coraz większym zakresie respektuje zagwarantowaną konstytucyjnie autonomię uczelni. Wyrazem tego jest m.in. nowelizacja z 18 marca $2011 \mathrm{r}^{28}$ znosząca wcześniejsze uprawnienie ministra właściwego do spraw szkolnictwa wyższego w postaci wydawania

5 Ustawa z dnia 14 czerwca 1960 r. (tekst jedn. Dz.U. z 2016 r., poz. 23 ze zm.).

26 Inny aspekt autonomii uczelni związany jest $\mathrm{z}$ indywidualną wolnością prowadzonych $\mathrm{w}$ nich badań naukowych i ogłaszania ich wyników oraz wolnością nauczania. H. Izdebski, J. Zieliński, Prawo o szkolnictwie wyższym. Komentarz, LEX/el 2015.

27 H. Izdebski, J. Zieliński, op. cit.

28 Dz.U. z 2011 r., nr 84, poz. 455. 
decyzji zatwierdzających ${ }^{29}$ statut uczelni. Odwołując się zatem do wykładni systemowej oraz wnioskowania prawniczego argumentum a maiori ad minus (z większego na mniejsze), stwierdzić można, że skoro prawo nie przewiduje uzgadniania (zatwierdzania) statutu uczelni, czyli aktu o podstawowym znaczeniu dla szkoły wyższej, to tym bardziej wymogu tego nie powinno się stosować do aktu wydawanego na zasadach określonych w statucie, czyli regulaminu muzeum uczelnianego. Wydaje się więc, że wymóg nadawania regulaminu w uzgodnieniu z ministrem właściwym do spraw kultury i ochrony dziedzictwa narodowego nie dotyczy regulaminów muzeów uczelnianych. Kwestie dotyczące tworzenia i funkcjonowania muzeów uczelnianych regulować będą statuty poszczególnych szkół wyższych. Stwierdzenie to potwierdza przepis art. 17 Prawa o szkolnictwie wyższym, zgodnie z którym sprawy związane z funkcjonowaniem uczelni, nieuregulowane w ustawie określa statut uczelni. Wskazane sformułowanie stanowi ważną gwarancję autonomii uczelni. Przepis ten, zdaniem H. Izdebskiego oraz J. Zielińskiego, jest upoważnieniem do uregulowania wszystkich nieokreślonych w prawie powszechnie obowiązującym spraw uczelni w taki sposób, „w jaki przewidują to organy uczelni lub władze i osoby, którym przysługuje uprawnienie do uchwalenia statutu"30. Wskazane upoważnienie to rodzaj nieznanej przepisom Konstytucji RP specyficznej „delegacji ustawowej” do wydania swoistych przepisów wykonawczych (o charakterze organizacyjnym), potwierdzającej konstytucyjnie umocowany status prawny uczelni. W literaturze podkreśla się, że istotą autonomii, w relacjach ad intra, jest rządzenie się własnym prawem, czyli ustanowionym specjalnie dla szkół wyższych prawem powszechnie obowiązującym, jak i prawem wewnętrznym ${ }^{31}$. Wydawane na podstawie ustawy statuty uczelni są szczególnymi aktami o mocy wewnętrznej, których przestrzeganie jest obowiązkiem danej społeczności akademickiej ${ }^{32}$. Akty te powinny dotyczyć spraw nieuregulowanych w ustawach i rozporządzeniach (a tego rodzaju kwestią jest np. funkcjonowanie muzeów uczelnianych), mieszcząc się jednocześnie w wyznaczonych przez upoważnienia ustawowe granicach ${ }^{33}$. Statut ma zasadnicze znaczenie dla kształtowania wewnętrznej struktury organizacyjnej uczelni. Zgodnie

29 Wymóg zatwierdzenia przez Ministra Obrony Narodowej lub ministra właściwego do spraw wewnętrznych dotyczy wyłącznie statutów uczelni wojskowych oraz uczelni służb państwowych, art. 56 ust. 5 P.sz.w.

${ }^{30}$ H. Izdebski, J. Zieliński, op. cit.

31 A. Wilczyńska, P. Wilczyński, Szkoły wyższe, w: Prawo administracyjne materialne, Wolters Kluwers, Warszawa 2016, s. 556-557.

32 H. Izdebski, J. Zieliński, op. cit.

33 Wyrok Sądu Najwyższego z dnia 19 marca 2008 r., I PK 227/07, LEX nr 465978. 
bowiem z przepisem art. $84 \mathrm{w}$ zW. $\mathrm{z}$ art. 17 P.sz.w. wszelkie uczelniane jednostki organizacyjne muszą być tworzone zgodnie ze statutem. Statuty poszczególnych uczelni mogą więc określać odmienne zasady tworzenia, przekształcania bądź likwidowania innych niż podstawowe jednostek organizacyjnych. Obowiązujące w tym zakresie wymogi mogą być bardziej lub mniej sformalizowane, np. statut może przewidywać tworzenie innych jednostek organizacyjnych zarządzeniem rektora (po zasięgnięciu opinii senatu lub bez konieczności zasięgania opinii) albo uchwałą senatu. Analiza statutów wybranych uczelni potwierdza tę tezę. Statuty niektórych szkół wyższych odnoszą się bowiem expressis verbis do muzeów jako jednostek ogólnouczelnianych ${ }^{34}$ lub jednostek wewnątrzwydziałowych ${ }^{35}$, inne zaś statuty nie regulują wprost kwestii muzeów uczelnianych ${ }^{36}$. Analizując zatem przepisy Prawa o szkolnictwie wyższym oraz ustawy o muzeach, należy podkreślić, że decyzja o utworzeniu muzeum uczelnianego jest wewnętrzną, autonomiczną sprawą danej jednostki naukowej. Muzea stanowić mogą zarówno jednostki ogólnouczelniane, jak i jednostki wydziałowe. Podstawą ich funkcjonowania powinny być regulaminy nadawane przez organizatora, w sposób określony w statucie danej uczelni. Przejawiająca się w dominującej roli regulacji statutowej autonomia organizacyjna uczelni umożliwia elastyczne dostosowanie postanowień regulaminów muzeów do istniejących warunków organizacyjnych, rzeczywistych możliwości i potrzeb danej uczelni. Tego rodzaju rozwiązanie

34 Np. § 76 Statutu Uniwersytetu Jagiellońskiego uchwalonego przez Senat Uniwersytetu Jagiellońskiego dnia 7 czerwca 2006 r. stanowi, że Muzeum Uniwersytetu Jagiellońskiego jest jednostką o zadaniach naukowych, oświatowych i dydaktycznych. Organizację oraz szczegółowe zadania Muzeum określa regulamin uchwalony przez Senat na wniosek dyrektora Muzeum. Zob. http:// www.uj.edu.pl/documents/10172/84592034/uchw_nr_60_2017_zal_1.pdf/2f9c1467-b33d-40c2-96de-7ad68335cdf5; stan na 30.04.2017 r.

35 Np. § 33 Statut Uniwersytetu Wrocławskiego stanowi, że w ramach wydziałów mogą działać jako jednostki organizacyjne: instytuty, katedry, zakłady, centra badawcze, centra dydaktyczno-badawcze, zespoły, pracownie, laboratoria, obserwatoria, stacje naukowe, sekcje, studia (studium), biblioteki, archiwa, ośrodki obliczeniowe, muzea [pogrubienie własne autorki], zakłady doświadczalne, jednostki usługowe i gospodarcze. Jednostki organizacyjne, jeżeli Statut nie stanowi inaczej, tworzy, przekształca i likwiduje Rektor w drodze zarządzenia wydanego na wniosek dziekana zgłoszony wraz z opinią rady wydziału. Zob. Uchwała Nr 32/2012 Senatu Uniwersytetu Wrocławskiego z dnia 25 kwietnia 2012 r. Statut Uniwersytetu Wrocławskiego, http://bip.uni.wroc.pl/download/attachment/9911/statut-uniwersytetu-wroclawskiego-tekstjednolity.pdf; stan na 10.04.2017 r.

36 Np. Statut Uniwersytetu Łódzkiego przyjęty uchwałą Senatu z dnia 26 czerwca 2006 r. nie stanowi wprost o muzeach uniwersyteckich. Statut zawiera ogólne postanowienia dotyczące trybu tworzenia jednostek międzywydziałowych, pozawydziałowych, ogólnouczelnianych i innych jednostek. Jednostki te tworzy, przekształca i likwiduje rektor. Zob. http://www.uni. lodz.pl/ouni/statut; stan na 10.04.2017 r. 
prawne uznać należy za w pełni uzasadnione. Regulaminy instytucji uczelnianych powinny spełniać wymogi treściowe określone w art. 6 ust. 2 u.m. Poza tym regulaminy nie mogą naruszać ani modyfikować regulacji ustawowej. Swoboda regulaminowego kształtowania ustroju i funkcjonowania muzeum uczelnianego dotyczy bowiem wyłącznie spraw nieuregulowanych w sposób wyraźny w ustawie. Zakres spraw pozostawionych do uznania uczelni jako organizatora muzeum dotyczy m.in. wskazania organu nadzorującego muzeum, ewentualnego ustanowienia organów doradczych i określenia sposobu ich powoływania. Do szkoły wyższej będącej organizatorem muzeum należy także decyzja o nieodpłatnym lub odpłatnym wstępie dla zwiedzających. W przypadku płatnego udostępniania zbiorów uczelnianych ustalenie i podanie do publicznej wiadomości wysokości opłat za wstęp do muzeum należy do obowiązków dyrektora tej instytucji ${ }^{37}$.

\section{Problematyczne zagadnienia dotyczące statusu prawnego muzeów uczelnianych}

Wątpliwości prawne dotyczące trybu nadawania regulaminów muzeom uczelnianym w dużej mierze odnieść można do problematyki sprawowania nadzoru nad nimi. Ustawa o muzeach w sposób jednolity reguluje wskazaną kwestię, stanowiąc w przepisie art. 8, że nadzór nad muzeami sprawuje minister właściwy do spraw kultury i ochrony dziedzictwa narodowego. Wskazany organ centralny może w tym celu dokonywać kontroli ich działalności. Jeżeli w wyniku kontroli stwierdzone zostanie rażące naruszenie przepisów ustawy i statutu muzeum, minister wzywa do usunięcia uchybień. Po bezskutecznym upływie wyznaczonego terminu, wskazany minister - po wysłuchaniu organizatora oraz rady muzeum (lub rady powierniczej), a także zapoznaniu się z opinią Rady do Spraw Muzeów - może zakazać muzeum dalszej działalności. Wskazane rozstrzygnięcie nadzorcze podejmowane jest w drodze decyzji administracyjnej. Analiza postanowień ustawowych prowadzi do wniosku, że ustawa o muzeach nie uwzględnia, albo czyni to jedynie w znikomym zakresie, problematyki nadzoru nad muzeami prywatnymi, a w szczególności instytucjami uczelnianymi. Ani ustawa o muzeach, ani Prawo o szkolnictwie wyższym nie stanowią o możliwości wydawania przez ministra właściwego do spraw kultury i ochrony dziedzictwa narodowego decyzji o zakazie prowadzenia działalności przez muzeum uczelniane. Zgodnie zaś z powoływanym wcześniej przepisem art. 4 ust. 5 Prawa o szkolnictwie

37 Por. art. 10 u.m. 
wyższym organy administracji rządowej moga podejmować decyzje dotyczące uczelni tylko $w$ przypadkach przewidzianych $w$ ustawach. Obowiązujące przepisy nie dają zatem podstawy prawnej dla wydania przez ministra właściwego do spraw kultury i ochrony dziedzictwa narodowego decyzji administracyjnej o zakazie działalności muzeum uczelnianego. Wydaje się zatem, iż tego rodzaju akt prawny jako wydany bez podstawy prawnej podlegałby stwierdzeniu nieważności w trybie art. 156 K.p.a. Ponadto przepis art. 8 ustawy o muzeach wskazuje, iż minister wydaje decyzję po wysłuchaniu organizatora oraz rady muzeum (lub rady powierniczej). Wskazane organy (rada muzeum; rada powiernicza) funkcjonują, co do zasady, wyłącznie przy instytucjach państwowych i samorządowych. Sprawowanie przez ministra właściwego do spraw kultury i ochrony dziedzictwa narodowego ogólnego nadzoru nad instytucjami uczelnianymi wydaje się nie mieć podstawy prawnej ${ }^{38}$. Nadzór nad uczelniami zgodnie z przepisami Prawa o szkolnictwie wyższym ma charakter nadzoru prawnego, co oznacza, że organ nadzoru może podejmować działalność nadzorczą wyłącznie w zakresie określonym przez ustawę oraz stosować tylko ustawowo przewidziane środki władcze. Zgodnie z art. 33 P.sz.w., nadzór nad zgodnością działań uczelni z przepisami prawa i statutem (treścią pozwolenia na utworzenie uczelni niepublicznej), a także nad prawidłowością wydatkowania środków publicznych sprawuje minister właściwy do spraw szkolnictwa wyższego. Minister może żądać informacji i wyjaśnień od organów uczelni oraz założyciela uczelni niepublicznej, a także dokonywać kontroli działalności uczelni. Biorąc pod uwagę powyższe, stwierdzić należy, że bezpośredni nadzór nad muzeum uczelnianym sprawować będzie organ wskazany w jego regulaminie danego muzeum. $Z$ kolei - na zasadach określonych w Prawie o szkolnictwie wyższym - muzea te podlegać będą także nadzorowi sprawowanemu przez ministra właściwego do spraw szkolnictwa wyższego.

W przypadku muzeów uczelnianych problematyczne wydaje się być egzekwowanie wymagań określonych w rozporządzeniu Ministra Kultury i Dziedzictwa Narodowego z dnia 2 września 2014 r. w sprawie zabezpieczania zbiorów muzeum przed pożarem, kradzieżą i innym niebezpieczeństwem, grożącym ich zniszczeniem lub utrata ${ }^{39}$. Ustanowione we wskazanym akcie prawnym techniczne wymogi dotyczące zabezpieczania zbiorów w dużej mierze przekraczają możli-

38 Należy podkreślić, iż w przypadku uczelni artystycznych uprawnienia ministra właściwego do spraw szkolnictwa wyższego w zakresie nadzoru sprawuje odpowiednio minister właściwy do spraw kultury i ochrony dziedzictwa narodowego. W tym przypadku brak możliwości wydawania decyzji o zakazie działalności muzeum uczelnianego może budzić pewne wątpliwości. Problematyka ta wykracza jednak poza ramy niniejszego opracowania.

39 Dz.U. z 2014 r., poz. 1240. 
wości organizacyjne, techniczne i finansowe muzeów uczelnianych. Stosowanie wymagań wskazanego rozporządzenia do omawianych jednostek często stanowiłoby nadmierne obciążenie dla uczelni, jak np. spełnienie wymogu zapewnienia odrębnej ochrony fizycznej. Nie w każdym przypadku byłoby to także niezbędne czy celowe, z uwagi na charakter i wartość (materialną i niematerialna) zgromadzonych zbiorów muzealnych. W przypadku muzeów uczelnianych zapewnienie bezpieczeństwa zgromadzonych zbiorów ciąży na uczelni. Przyjęte w tej sferze rozwiązania powinny stanowić wynik uzgodnień dokonanych pomiędzy dyrektorem (kierownikiem) muzeum a właściwym organem uczelni. Jednocześnie należy podkreślić, iż utworzenie muzeum uczelnianego równoznaczne jest z przyjęciem przez organizatora odpowiedzialności za zgromadzone zbiory i dążeniem do odpowiedniego zabezpieczenia przed pożarem, kradzieżą i innymi niebezpieczeństwami grożącymi zniszczeniem lub utratą posiadanych kolekcji.

Kolejną dyskusyjną kwestią jest status prawny pracowników muzeów uczelnianych. Przepisy dotyczące pracowników muzeów zostały istotnie znowelizowane ustawą z dnia 5 sierpnia 2015 r. o zmianie ustaw regulujących warunki dostępu do wykonywania niektórych zawodów $\mathrm{w}^{40}$. Zgodnie z obecnym brzmieniem art. 32 ustawy o muzeach pracownicy zatrudnieni na stanowiskach, na których realizuje się zadania związane $\mathrm{z}$ gromadzeniem i naukowym opracowywaniem zbiorów, urząadzaniem wystaw i udostępnianiem zbiorów do celów edukacyjnych i naukowych, organizowaniem badań i ekspedycji naukowych, w tym archeologicznych, a także prowadzeniem działalności edukacyjnej, artystycznej, upowszechniającej kulturę lub działalności wydawniczej, tworzą grupę zawodową muzealników. Grupę zawodową muzealników stanowią kustosze dyplomowani, kustosze, adiunkci i asystenci. Sąd Najwyższy w wyroku z dnia 3 września $2013 \mathrm{r} \mathrm{r}^{41}$ stwierdził, że określenia zawodowe: asystent, adiunkt, kustosz oraz kustosz dyplomowany pracowników zatrudnionych w muzeach należy traktować jako tytuły zawodowe. Określają one muzealników i ich specjalizację oraz rangę stanowisk zajmowanych przez poszczególnych pracowników muzeów. Wskazane tytuły zawodowe nie oznaczają natomiast powierzenia określonego rodzaju pracy w zrozumieniu Kodeksu pracy. Zdaniem SN, pracownik muzeum nie może być zatrudniony na stanowisku ,adiunkta” bez dokładnego określenia jego obowiązków pracowniczych, obowiązki te wyznaczają bowiem rodzaj powierzonej pracy i determinują określenie stanowiska pracy związanego z działalnością

40 Dz.U. z 2015 r., poz. 1505.

41 Sygn. akt I PK 37/13, Lex nr 1541139. Podobnie wyrok Sądu Najwyższego z 9 marca 2011 r., II PK 225/10, OSNP 2012, nr 9-10, poz. 112. 
podstawową muzeum. Dlatego, w ocenie Sądu, pojęcia adiunkt, asystent, kustosz i kustosz dyplomowany stanowią raczej tytuły zawodowe, a nie oznaczają rodzaju powierzonej pracy, czyli stanowiska pracy w rozumieniu Kodeksu pracy. Poza grupą muzealników, w muzeach mogą być zatrudniani specjaliści w zawodach związanych działalnością muzealniczą. Specjaliści realizują zadania związane z przechowywaniem i katalogowaniem gromadzonych zbiorów, zabezpieczaniem i konserwacją zbiorów, w tym zabytków nieruchomych oraz nieruchomych obiektów kultury materialnej i przyrody oraz zapewnieniem właściwych warunków zwiedzania muzeum i korzystania ze zbiorów. Wskazane osoby zatrudniane są na stanowiskach: 1) starszego konserwatora; 2) konserwatora; 3) adiunkta konserwatorskiego; 4) starszego asystenta konserwatorskiego; 5) asystenta konserwatorskiego; 6) starszego dokumentalisty; 7) dokumentalisty; 8) młodszego dokumentalisty; 9) starszego renowatora; 10) renowatora; 11) renowatora przyuczonego; 12) młodszego renowatora; 13) przewodnika. Niezbędne kwalifikacje oraz doświadczenie zawodowe wymagane na poszczególnych stanowiskach w grupie muzealników oraz specjalistów określają przepisy ustawy o muzeach. Posiadanie wymaganych na poszczególnych stanowiskach kwalifikacji stwierdza pracodawca, przy czym w przypadku stanowiska kustosza dyplomowanego i kustosza wymagane jest dodatkowo zaświadczenie o posiadaniu dorobku zawodowego. Posiadanie wymaganego dorobku zawodowego lub jego brak stwierdza minister właściwy do spraw kultury i ochrony dziedzictwa narodowego, wydając odpowiednie zaświadczenie ${ }^{42}$. Przyjęcie wskazanego rozwiązania budzi jednak pewne uwagi. W orzecznictwie ${ }^{43}$ sądowoadministracyjnym podkreśla się bowiem, iż sprawa administracyjna powinna być załatwiona $\mathrm{w}$ formie przewidzianej przez prawo, czyli w tym przypadku w formie zaświadczenia. Jednakże odmowa pozytywnego załatwienia sprawy ${ }^{44}$ przez organ administracji publicznej powinna przybierać formę decyzji administracyjnej ${ }^{45}$. Wskazane rozwiązanie umożliwia bowiem sądową kontrolę tego aktu, co ma podstawowe znaczenie z punktu widzenia interesów podmiotów administrowanych (czyli podmiotów spoza administracji publicznej) oraz zapewnienia obiektywnego porządku prawnego.

W przypadku muzeów uczelnianych zagadnieniem otwartym pozostaje kwestia zatrudniania w nich pracowników na - określonych w ustawie o muzeach - etatach muzealników i specjalistów. W myśl art. 107 P.sz.w. pracownikami uczelni

42 Por. art. 33c ust. 2 u.m.

43 Por. wyrok WSA w Warszawie z dnia 19 czerwca 2006 r., III SA/Wa 393/06.

${ }^{44} \mathrm{~W}$ tym przypadku będzie to odmowa stwierdzenia wymaganego na stanowisko kustosza (kustosza dyplomowanego) dorobku zawodowego.

45 Wyrok WSA w Warszawie z dnia 19 czerwca 2006 r., op. cit. 
są nauczyciele akademiccy oraz pracownicy niebędący nauczycielami akademickimi. Ustawa zawiera zamknięty katalog stanowisk, na których zatrudniani są nauczyciele akademiccy, nie przewidując w tej grupie muzealników. Z kolei kategoria pracowników niebędących nauczycielami akademickimi jest otwarta. Przepisy stanowiąjedynie, że pracownicy niebędący nauczycielami akademickimi zatrudniani są na podstawie umowy o pracę. Umowę o pracę zawiera rektor lub inny organ uczelni wskazany w statucie. Wydaje się zatem, iż obowiązujące przepisy nie stoją na przeszkodzie wyodrębnieniu w uczelni grupy zawodowej muzealników i specjalistów w zawodach dotyczących działalności muzealniczej. Zaliczenie grupy muzealników do kategorii nauczycieli akademickich budzi jednak uzasadnione wątpliwości. Obowiązujące przepisy w sposób zamknięty i szczegółowy regulują bowiem kwestię zatrudniania nauczycieli akademickich, a statut uczelni lub inne akty wewnątrzuczelniane nie mogą modyfikować postanowień ustawowych. Także ustawa o muzeach nie daje podstaw prawnych do zaliczenia grupy zawodowej muzealników do grona nauczycieli akademickich. Ustawa ta jako główny cel muzeów wskazuje bowiem gromadzenie i ochronę dóbr naturalnego i kulturalnego dziedzictwa ludzkości, informowanie o wartościach i treściach gromadzonych zbiorów, upowszechnianie podstawowych wartości historii, nauki i kultury polskiej oraz światowej, kształtowanie wrażliwości poznawczej i estetycznej oraz umożliwianie korzystania ze zgromadzonych zbiorów. Ustawa o muzeach nie eksponuje natomiast konieczności prowadzenia przez muzea działalności naukowej ${ }^{46}$. Podjęcie decyzji w sprawie utworzenia stanowisk muzealników lub specjalistów muzealnych na danej uczelni należy do rektora jako przełożonego wszystkich pracowników uczelni. Przy czym wskazane rozstrzygnięcie powinno być uzależnione od oceny funkcjonowania danego muzeum oraz zakresu, charakteru i jakości podejmowanych w nim działań. Wydaje się, iż w przypadku utworzenia na uczelni grupy zawodowej muzealników do statusu pracowniczego tej grupy zastosowanie będą mieć przepisy ustawy z 1991 r. o organizowaniu i prowadzeniu działalności kulturalnej dotyczące

46 Inaczej kwestia ta uregulowana jest w przypadku bibliotek naukowych, których organizatorami są szkoły wyższe. Zgodnie z art. 21 ustawy o bibliotekach, biblioteki naukowe służą potrzebom nauki i kształcenia, zapewniając dostęp do materiałów bibliotecznych i zasobów informacyjnych niezbędnych do prowadzenia prac naukowo-badawczych oraz zawierających wyniki badań naukowych. Rolą wskazanych jednostek jest także prowadzenie działalności naukowo-badawczej w zakresie bibliotekoznawstwa i dziedzin pokrewnych, a także w zakresie obsługiwanych przez nie dziedzin nauki. $Z$ uwagi na tak wyznaczony zakres działalności, spełniający ustawowo określone kryteria pracownicy bibliotek uczelnianych zaliczani są do kategorii nauczycieli akademickich. Ustawa z dnia 27 czerwca 1997 r. o bibliotekach (tekst jedn. Dz.U. z 2012 r., poz. 642 ze zm.). 
pracowników instytucji kultury. Wyodrębnienie grupy muzealników w muzeach uczelnianych przyczynić by się mogło do profesjonalizacji funkcjonowania omawianych jednostek, z uwagi na konieczność posiadania określonych w ustawie o muzeach kwalifikacji do zajmowania poszczególnych stanowisk muzealników (czyli stanowiska kustosza dyplomowanego, kustosza, adiunkta i asystenta). Pracownicy muzeów uczelnianych jako muzealnicy zobowiązani zostaliby także do przestrzegania ogólnie przyjętych norm etyki zawodowej, zawartych w Kodeksie Etyki dla Muzeów Międzynarodowej Rady ds. Muzeów (ICOM) ${ }^{47}$. Pracowników tychże muzeów dotyczyłby również ustawowy ${ }^{48}$ zakaz prowadzenia działalności handlowej przedmiotami pozostającymi w zakresie zainteresowania muzeum, a także podejmowania działań kolekcjonerskich i wykonywania ekspertyz i wycen przedmiotów, jeżeli mogłoby to powodować konflikt interesów prywatnych z interesem muzeum, w którym dana osoba pracuje.

\section{Zakończenie}

Konkludując, zauważyć należy, że muzea uczelniane stanowią formę organizowania i prowadzenia działalności kulturalnej. Tego rodzaju instytucje oprócz podstawowych celów związanych z gromadzeniem i trwałą ochroną dóbr naturalnego i kulturalnego dziedzictwa ludzkości realizują także dodatkowe zadania wynikające z usytuowania muzeum jako jednostki uczelnianej. Muzea szkół wyższych aktywnie uczestniczą w działalności naukowej, dydaktycznej, a także oświatowej. Okoliczność ta w dużej mierze przybliża je do starożytnych pierwowzorów muzeów, czyli pozostających pod opieką muz ośrodków naukowych. Regulacje prawne dotyczące statusu prawnego muzeów uczelnianych są jednak bardzo lakoniczne, co może rodzić wątpliwości interpretacyjne dotyczące np. trybu tworzenia tych jednostek oraz statusu pracowniczego osób w nich zatrudnionych. Szereg spraw dotyczących muzeów szkół wyższych pozostawiony został do uznania uczelni, która w drodze statutu określa szczegółowe kwestie dotyczące swojej struktury organizacyjnej. Rozwiązanie takie, pozostając w zgodzie z zasadą autonomii uczelni, umożliwia jej prowadzenie samodzielnej polityki rozwoju. Szkoła wyższa, tworząc muzea, przyjmuje na siebie zobowiązania organizatora, czyli obowiązek zapewnienia środków potrzebnych do utrzymania i rozwoju jednostki, zapewnienia bezpieczeństwa zgromadzonym zbiorom,

\footnotetext{
${ }_{47} \mathrm{~W}$ polskim systemie prawnym nie istnieją bowiem odrębne przepisy dotyczące obowiązków etycznych muzealników.

48 Por. art. u.m.
} 
a także obowiązek sprawowania nadzoru nad działalnością muzeum ${ }^{49}$. Należy podkreślić, że muzeum uczelniane stanowi wyraz potencjału, zaangażowania i możliwości organizacyjnych swojej Alma Mater. Omawiane instytucje kultury stanowią praktyczną formę udoskonalania i uatrakcyjniania procesu naukowego i dydaktycznego. Powoływanie wskazanych jednostek świadczy o zrozumieniu współczesnego podejścia do zagadnień upowszechniania nauki i procesu dydaktycznego. Tradycyjne formy podawania wiedzy ex cathedra stają się bowiem obecnie w dużej mierze niewystarczające dla zaspokojenia oczekiwań i potrzeb studentów. Muzea uczelniane otwarte i dostępne także dla osób spoza uczelni stanowią zatem doskonałą odpowiedź szkół wyższych na wyzwania współczesności.

\section{Bibliografia}

\section{Akty prawne}

Konstytucja RP z dnia 2 kwietnia 1997 r. (Dz.U., nr 78, poz. 483 ze zm.).

Ustawa z dnia 14 czerwca 1960 r. Kodeks postępowania administracyjnego (tekst jedn. Dz.U. z 2016 r., poz. 23 ze zm.).

Ustawa z dnia 25 października 1991 r. o organizowaniu i prowadzeniu działalności kulturalnej (tekst jedn. Dz.U. z 2012 r., poz. 406 ze zm.).

Ustawa z dnia 21 listopada 1996 r. o muzeach (tekst jedn. Dz.U. z 2012 r., poz. 987 ze zm.).

Ustawa z dnia 27 czerwca 1997 r. o bibliotekach (tekst jedn. Dz.U. z 2012 r., poz. 642 ze zm.).

Ustawa z dnia 27 lipca 2005 r. Prawo o szkolnictwie wyższym (tekst jedn. Dz.U. z 2016 r., poz.1842 ze zm.).

Ustawa z dnia 5 sierpnia 2015 r. o zmianie ustaw regulujących warunki dostępu do wykonywania niektórych zawodów (Dz.U. z 2015 r., poz. 1505).

Rozporządzenie Rady Ministrów z dnia 24 grudnia 2007 r. w sprawie Polskiej Klasyfikacji Działalności (PKD) (Dz.U. z 2007 r., nr 251, poz. 1885 ze zm.).

\section{Opracowania}

Antoniak Patrycja, Ustawa o muzeach. Komentarz, Wolters Kluwer, Warszawa 2012.

Czarnik Zbigniew, Posłuszny Jerzy, Zakład publiczny, w: Roman Hauser, Zygmunt Niewiadomski, Andrzej Wróbel (red.), System Prawa Administracyjnego, t. 6, Podmioty administrujace, C.H. Beck, Warszawa 2011.

Izdebski Hubert, Zieliński Jan M., Prawo o szkolnictwie wyższym. Komentarz, LEX/el 2015.

Jendrośka Jan, Zakład administracyjny, w: Jan Boć (red.), Prawo administracyjne, Kolonia Limited, Wrocław 2007.

Karcz-Kaczmarek Maria, Rola samorząów zawodowych $w$ dostępie do niektórych zawodów, w: Prawo administracyjne materialne, Wolters Kluwer, Warszawa 2016.

Komornicki Stefan, Dobrowolski Tadeusz (red.), Muzealnictwo: praca zbiorowa, Związek Muzeów w Polsce, Kraków 1947.

49 Por. art. 5 ust. 4 u.m. 
Kosowski Miron, Chetm 8 VI 1794, Inforteditions, Zabrze 2014.

Mansfeld Bogusław, Muzea na drodze do samoorganizacji, DiG, Warszawa 2000.

Pruszyński Jan, Ochrona zabytków w Polsce. Geneza, organizacja, prawo, PWN, Warszawa 1989.

Wilczyńska Agnieszka, Wilczyński Przemysław, Szkoły wyższe, w: Prawo administracyjne materialne, Wolters Kluwers, Warszawa 2016.

Żygulski Zdzisław Jr, Muzea na świecie. Wstęp do muzealnictwa, PWN, Warszawa 1982.

\section{Strony internetowe}

http://icom.museum/fileadmin/user_upload/pdf/Codes/poland.pdf; stan na 10.04.2017 r.

http://orka.sejm.gov.pl/Druki5ka.nsf/0/E44B010685003C90C12572BA00646C81/\$file/1598. pdf; stan na 01.04.2017 r.

http://www.uj.edu.pl/documents/10172/84592034/uchw_nr_60_2017_zal_1.pdf/2f9c1467-b33d-40c2-96de-7ad68335cdf5; stan na 30.04.2017 r.

http://bip.uni.wroc.pl/download/attachment/9911/statut-uniwersytetu-wroclawskiego-tekstjednolity.pdf; stan na 10.04.2017 r.

http://www.nra.pl/nra.php?id=786; stan na 01.03.2017 r.

https://pl.wikipedia.org/wiki/Muzeum; stan na 10.04.2017 r.

https://www.uni.lodz.pl/ouni/statut; stan na 10.04.2017 r.

Maria KARCZ-KACZMAREK

\section{LEGAL STATUS OF UNIVERSITY MUSEUMS - LEGAL ISSUES AND PRACTICAL CHALLENGES}

( Sum mary)

College (university) museums are organizational form of cultural activities. That kind of institutions - due to situating as part of the higher education institution - apart from basic aims of museums, such as accumulation and the permanent protection of goods of the natural and cultural legacy mankindes are carrying out also additional tasks concerning the participation in the teaching, as well as educational scientific activity. Generally applicable provisions don't refer directly to issues of college museums, these issues are regulating the articles of university statutes. Such a solution constitutes the respect for the autonomy of higher education institutions, as well as enables them to lead creative development policies. Creating college museums is a valuable form of improving and making more appealing the scientific and teaching process.

Keywords: legal issues of museum; legal status of university museums; statutes of universities; autonomy of university (college) 